Mariola WoŁK

Uniwersytet Warmińsko-Mazurski

Instytut Filologii Polskiej

\title{
O układach typu ___. (To) Nonsens. (vs to nonsens, że_) z semantycznego punktu widzenia
}

Słowa klucze: współczesny język polski, semantyka leksykalna, składnia

1. Zakres tego szkicu jest szerszy, aniżeli sugeruje jego tytuł. W niniejszym tekście chciałabym bowiem rozwinąc wątek rozpoczęty w kilku innych moich pracach na temat wyrażenia nonsens, a także niektórych jego bliskoznaczników. A ponieważ wątek ten wywołuje szereg kolejnych problemów również poruszanych przeze mnie wcześniej, należałoby mówić o frontalnym podjęciu tematów dotychczas jedynie sygnalizowanych lub towarzyszących analizie innych centralnych zagadnień związanych z nonsensem. Chodzi mi mianowicie przede wszystkim o pewien typ konfiguracji, w jakich występuje słowo nonsens $\mathrm{i}$ takie wyrażenia, jak absurd i bzdura. Nawet pobieżny przegląd tekstowych realizacji tych wyrażeń pokazuje, że do najczęściej spotykanych należą takie konteksty, jak np.:

(1) Sekretarka krzyczy na swego szefa. To absurd.

(2) Graja byle gdzie, żeby byto taniej, bez dekoracji, bez światet. Absurd!

(3) Piotr kupit sobie mieszkanie w Warszawie. Nonsens!

(4) Marysia uciekła wczoraj z ostatniej lekcji. To nonsens!

(5) Anna ma już trzeciego męża. To bzdura!

(6) Magda podpisala się pod tym wnioskiem. Bzdury!, 
nazywane przeze mnie umownie komentującymi (por. Wołk 2007a: 179), bo interesujące mnie wyrażenia pełnią w nich funkcję komentarza (odpowiadającego w strukturze tematyczno-rematycznej zdania rematowi) do poprzedzającego go wypowiedzenia (które w strukturze tematyczno-rematycznej odpowiada tematowi) deskryptywnie ujmującego zjawisko, któremu przypisuje się cechy nonsensu, bzdury czy absurdu. Mimo że punktem dojścia w tych rozważaniach będzie - zgodnie z tytułową zapowiedzią - sformułowanie wniosków dotyczących semantycznych właściwości analizowanych wyrażeń występujących w tych układach, w pierwszej kolejności przyjrzę się ich statusowi gramatycznemu.

Charakterystyczne dla opisywanych układów jest to, że słowa te stanowią w nich syntaktycznie odrębne byty, formalnie niezależne od poprzedzającej je, deskryptywnej części wypowiedzi. $Z$ tego powodu moga pretendować do roli asyntagmatyków (leksemów funkcjonujących samodzielnie jako wypowiedzenia), do których zalicza się wykrzykniki i dopowiedzenia (por. np. klasyfikacje leksemów autorstwa R. Laskowskiego 1999: 59 i M. Grochowskiego 1997: 12-14) różniące się od siebie zależnością od kontekstu. Wykrzykniki są niezależne od kontekstu werbalnego, a dopowiedzenia są od niego zależne, ponieważ implikują istnienie tekstu. Odrębność wypowiedzeniowa badanych wyrażeń z przykładów (1)-(6) skłania do odpowiedzi na pytanie, czy rzeczywiście należałoby je zaliczyć do którejś z tych dwóch grup, a jeśli tak, to do której.

Pewne jest, że wszystkie one domagają się kontekstu dookreślającego komentowany stan rzeczy i jednocześnie motywującego pojawienie się tych słów w funkcji wypowiedzenia. Tyle że o ile w wypadku absurdu nie musi to być (i zwykle nie jest) kontekst werbalny, o tyle nonsens i bzdure zawsze wywołuje jakaś myśl, najczęściej utrwalona w języku. Zatem wyrażenie absurd z przykładu (1) nie musi być poprzedzone zdaniem relacjonującym to, że sekretarka upomina swego szefa, ale konieczna jest sytuacja, na którą mówiący zareaguje wypowiedzeniem tego słowa, sytuacja, która miała miejsce (a mówiący był jej obserwatorem bądź uczestnikiem) lub mogłaby mieć miejsce (zdarzenie potencjalne), przy czym w tym drugim wypadku należałoby de facto mówić o myśli o danej sytuacji. Natomiast wyrażenia nonsens i bzdura są zwykle reakcjami na czyjeś powiedzenie czegoś (o czymś). Jeśliby więc zdania towarzyszące im w przykładach (3)-(6) nie zostały zwerbalizowane, musiałyby przybrać kształt czegoś w rodzaju mowy wewnętrznej, myśli układających się w czyimś umyśle w dialog, skwitowany wyrażeniem nonsens czy bzdura. Z punktu widzenia różnicy między wykrzyknikami 
a dopowiedzeniami absurd wydaje się bliski wykrzyknikom, a nonsens i bzdura dopowiedzeniom.

W informacji gramatycznej zamieszczonej w słownikach współczesnej polszczyzny na ogół pomija się takie konteksty występowania tych wyrażeń (np. SJPSz, SWJP, PSWP, USJP) ${ }^{1}$, jedynie w ISJP odróżnia się je od innych użyć i kwalifikuje jako wykrzykniki (por. ISJP I: 4, 146, 1041). Trudno jednak się z tym zgodzić, podobnie jak trudno bez choćby cienia wątpliwości przystać na hipotezę o dopowiedzeniowym charakterze nonsensu i bzdury. Problem statusu gramatycznego wyrażeń tożsamych kształtowo m.in. z rzeczownikami i zdolnych do występowania w funkcji wypowiedzeń kontekstowo zależnych poruszał w swoich pracach Adam Dobaczewski $(1995,1998,1999)$ próbujący oddzielić interesujące go dopowiedzenia potwierdzające od wypowiedzeń wprawdzie również niesamodzielnych tekstowo, ale dopowiedzeniami nie będących, bo występujących wtórnie w funkcji wypowiedzenia zależnego kontekstowo ${ }^{2}$. Jednym z warunków, jakie autor stawia takim wypowiedzeniom występującym w kontekście $q-E$, jest możliwość dodania do $E$ wyrażenia anaforycznego (zaimka to) odnoszącego się do $q$, , wraz z $q$ wprowadzonym przez spójnik podrzędny że (To E, że q / Że q, to E), przy zachowaniu tożsamości sensu $E$ i To (jest) E, że q w kontekście q" (Dobaczewski 1998: 32). W wypadku analizowanych tu wyrażeń chodziłoby zatem o przekształcenie konstrukcji ze słowem nonsens (odpowiadającym $E$ w przytoczonym wyżej zapisie), użytym jako luźny komentarz, niezależny syntaktycznie od poprzedzającego go wypowiedzenia (odpowiadającego $q$ ), w konstrukcję zdaniową o postaci to nonsens, że $q$ (dalej zapisywane jako to nonsens, że_). Wszystkie opisywane tu wyrażenia bez trudu poddają się takiej operacji, por.:

(7) To absurd, że sekretarka krzyczy na swego szefa.

(8) To absurd, że graja byle gdzie, żeby byto taniej, bez dekoracji, bez światel.

(9) To nonsens, że Piotr kupit sobie mieszkanie w Warszawie.

(10) To nonsens, że Marysia uciekła wczoraj z ostatniej lekcji.

1 W żadnym z wymienionych słowników nie zauważa się odmienności tego typu użyć i kwalifikuje słowa absurd, bzdura i nonsens jako rzeczowniki, choć w SWJP dziwi to, że rzeczownikowe użycie wyrażenia bzdura ilustruje się za pomocą przykładu: Podobno Wojtek się rozwodzi. - Bzdura! (por. SWJP: 90).

2 Nie sposób zgodzić się z M. Wiśniewskim (1995), który wyrażenia typu oczywiście, $\dot{z} e$, pewnie, że, właśnie, ̇̇e_proponuje zaliczać do klasy partykuł. O dyskusyjności takiego rozwiązania zob. Dobaczewski 1998: 37, przypis 18. 
(11) To bzdura, że Anna ma już trzeciego męża.

(12) To bzdury, że Magda podpisała się pod tym wnioskiem.

Zanim jednak przyjrzę się bliżej tym kontekstom, chciałabym zwrócić uwagę na to, że możliwość dodania zaimka to do badanych wyrażeń w użyciach ilustrowanych w przykładach (1)-(6) odróżnia je również wyraźnie od klasy wykrzykników³ ${ }^{3}$ Na przykład ktoś, kto będzie świadkiem sytuacji, w której sekretarka krzyczy na swego szefa (lub będzie szefem zdominowanym przez sekretarkę), może zareagować na jej zachowanie okrzykiem Absurd!, ale może też powiedzieć To absurd. (por. przykład (1)). Taka wariantywność, znamienna również dla przymiotników i przysłówków wtórnie użytych w funkcji wypowiedzenia (por. np. to zaskakujace / zadziwiajace / niebywałe / straszne, to cudownie / dobrze / fatalnie / szkoda), nie przysługuje jednostkom stricte wykrzyknikowym, takim jak np. ojej, rany boskie czy fuj. Jasne jest, że ktoś, kto odczuwa ból, może uzewnętrznić swoje emocje, wydając okrzyki Ojej!, Ojej! Ale boli! (lub Ale boli. Ojej!), ale powiedzenie *To ojej! lub *To ojej! Ale boli! są nie do przyjęcia, podobnie jak wypowiedzenia *To rany boskie, *To fuj. ${ }^{4}$

Interesujące mnie wyrażenia $w$ analizowanych kontekstach (To) Nonsens. nie są więc ani wykrzyknikami, ani dopowiedzeniami, co więcej, nie są także - wbrew przyjętemu na początku milcząco założeniu - asyntagmatykami. Właśnie za sprawą mogącego im towarzyszyć zaimka to, który nie jest bynajmniej jedynym słowem dającym się dostawić do opisywanych wyrażeń w rozważanych tu układach (por. np. wypowiedzenia w rodzaju: To jakiś nonsens / absurd!, Czysty nonsens / absurd!, Co za bzdura!, Ale bzdura!). Możliwość sprowadzenia ich do typowo predykatywnej postaci to nonsens, $\dot{z} e \_$stanowi według mnie wystarczający argument przemawiający za tym, by uznać je za warianty tych zdaniowych (propozycjonalnych) kontekstów, wtórnie występujące w funkcji kontekstowo zależnego wypowiedzenia.

2. Pierwszym spostrzeżeniem, które nasuwa się nawet po bardzo wstępnej obserwacji kontekstów typu (1)-(6) o postaci . (To) Nonsens. z kontekstami typu (7)-(12) o postaci to nonsens, że_, jest myśl o naturalności tych pierwszych kontrastującej z wymuszonością tych drugich. Zdania takie, jak w przykładach

3 Wspominałam o tym w swojej wcześniejszej pracy, por. Wołk (2007a: 179).

4 Oczywiście jeśliby potraktować ten przykład jako skierowane do dziecka predykatywne użycie $f u j$, z elidowanym członem jest i towarzyszącym mu gestem wskazującym, to niczego nie będzie można mu zarzucić. 
(7)-(12) spotyka się nieporównanie rzadziej niż (1)-(6), nie są one jednak sztucznymi konstruktami, nie występującymi w żywej mowie, bo w pewnych sytuacjach ich pojawienie się właśnie w takim kształcie wydaje się zupełnie naturalne. Mam tu na myśli konteksty dialogowe, w których będą one wypowiedziami-reakcjami (termin ten przejmuję od Jolanty Chojak 2006: 30) na inne wypowiedzi, które można by wstępnie nazywać (również za Chojak 2006) wypowiedziami-akcjami. Jeśliby więc przykłady (7)-(12) podać raz jeszcze w zmodyfikowanej wersji dialogowej, to nie można by im według mnie nic zarzucić. Por. np.:

(7') Nasza sekretarka ostatnio zachowuje się bardzo obcesowo. Wyobraź sobie, że zdarza jej się nawet krzyczeć na szefa. - To absurd, że sekretarka krzyczy na swego szefa.

(8') Ci aktorzy, choć bardzo młodzi, sq wyjatkowo utalentowani. Ale nie stać ich na podstawowe rekwizyty i wyposażenie, stad taki efekt. - To absurd, że graja byle gdzie, żeby byto taniej, bez dekoracji, bez światel.

(9') Piotr wyjechat do Warszawy, kupit sobie tam mieszkanie i teraz sie urzadza. - To nonsens, że Piotr kupit sobie mieszkanie w Warszawie. (Wiem, że mieszka katem u znajomych).

(10') Z Marysia dzieje się coś niedobrego, wczoraj uciekła z ostatniej lekcji. - To nonsens, że Marysia uciekła wczoraj z ostatniej lekcji. (Nie było jej w szkole cały dzień).

(11') Anna zachowuje się zupetnie inaczej niż kiedyś. Zmienia mężczyzn jak rękawiczki, ma już trzeciego męża. - To bzdura, że Anna ma już trzeciego męża. (Marek jest jej drugim partnerem i nie jest jej mężem).

(12') W tej aferze najbardziej ucierpi Magda, bo to ona podpisała sie pod wnioskiem o awans Kowalskiego. - To bzdury, że Magda podpisała się pod tym wnioskiem. (Była wtedy na urlopie).

Zgodnie z tym, co wcześniej stwierdziłam na temat typu kontekstu charakterystycznego dla komentujących użyć słowa absurd, przykłady (7) i (8) są empiryczne nawet wówczas, gdy pozbawimy je wypowiedzi-akcji. Natomiast wyrażenia nonsens i bzdura w układach to nonsens / bzdura, że_wymagają kontekstu werbalnego, ponieważ są reakcjami słownymi na czyjeś powiedzenie czegoś (o czymś).

W tym miejscu należałoby zdjąć z używanej w moich wcześniejszych pracach (por. np. Wołk 2007a: 186, Wołk 2007b: 296 (przypis 3), Wołk 2007c: 412) umownie etykiety metajęzykowości zasłonę milczenia i explicite ując związek 
tych dwóch wyrażeń z językiem. Mimo że przed chwilą chętnie przejęłam terminy wprowadzone przez J. Chojak, nie uznałabym wyrażeń to nonsens, że_za konstrukcje relacjonujące dialog. Według teorii Chojak na dialog, jako na sytuację komunikacyjną wymagającą rozbudowania (podwojenia) aktu mownego, składają się dwa elementy: 1) tworzenie specyficznej osobowej relacji nadawczo-odbiorczej przejawiające się w samym fakcie zwrócenia się do kogoś, 2) wymienność ról w tej relacji polegająca na tym, że ktoś mówi coś do kogoś ponieważ wcześniej ktoś powiedział coś do kogoś (por. Chojak 2006: 26). Tymczasem więź dialogowa w wypadku wypowiedzeń z opisywanymi wyrażeniami (zarówno w przykładach (1)-(6), jak i (7')-(12')) wydaje się nieistotna, ponieważ wypowiedzenia te wcale nie muszą być nastawione na dalsze wymienianie myśli, nie zawsze też są kierowane do przedmówcy. Nietrudno wyobrazić sobie sytuację, w której wypowiadany sąd będzie zwerbalizowanym fragmentem mowy wewnętrznej, na przykład jeśli ktoś, kto znajduje się w jakimś pomieszczeniu sam, zareaguje na wypowiedź usłyszaną w radiu lub telewizji wypowiedzeniem słów nonsens lub bzdura (przykłady (7)-(12) mogłyby z powodzeniem być reakcjami na kwestie wypowiedziane w jakiejś telenoweli). Mamy tu więc do czynienia nie tyle $\mathrm{z}$ dialogiem (ex definitione nastawionym na kontynuowanie), ile z reakcją słowną na czyjeś powiedzenie czegoś (o czymś), reakcją często niekontynuowaną, ale - co istotne - wywołaną przez czyjąś wypow i e dź. Bo jest to de facto mówienie czegoś o czymś, co ktoś wcześniej powiedział, a nie mówienie do kogośs. Wniosek ten dotyczy również analizowanych wyrażeń występujących w kontekstach komentujących.

3. Można by się było spodziewać, że układy komentujące, z racji syntaktycznego odcięcia interesujących mnie wyrażeń od poprzedzających je wypowiedzeń, będa - pod względem przyjmowania różnego typu fraz na otwierane przez badane predykaty miejsca walencyjne - bardziej liberalne niż układy propozycjonalne, w których badane wyrażenia są jedynie składnikami wypowiedzeń uzupełnianych o zdanie podrzędne wprowadzane przez że. Tymczasem różnice między nimi są niewielkie.

5 O różnicy między powiedzeniem czegoś komuś a powiedzeniem czegoś do kogoś pisała A. Wierzbicka (1973: 202-205). Rzecz sprowadza się głównie do tego, że mówiący do kogoś chce, żeby osoba, do której mówi, myślała, że mówiąc „ty”, myśli o niej właśnie. W powiedzeniu czegoś komuś tego komponentu nie ma. 
Jasne jest, że w zdaniach z wyrażeniem to nonsens, $\dot{z} e$ _ po że mogą pojawić się jedynie zdania oznajmujące, por. niepoprawne: *To nonsens, że idź na koncert / kup mieszkanie w Warszawie. I choć nie da się nic zarzucić pytaniu To nonsens, że on kupil mieszkanie $w$ Warszawie $?^{6}$, to znak zapytania (a w realizacji werbalnej antykadencja) obejmuje tu całe wypowiedzenie, włącznie z konstytuującym je predykatem. Również w układach komentujących najbardziej naturalne sąsiedztwo dla analizowanych wyrażeń stanowią konstatacje. Wypowiedzenia o postaci Nonsens. / Absurd. / Bzdura. mogą wprawdzie poprzedzać pytania, por. np.:

(13) Bronić się w szpitalu? Nonsens!

(14) Grać byle gdzie, bez dekoracji, bez światet, żeby było taniej? To absurd!

(15) Magda podpisała się pod tym wnioskiem? Bzdury!,

ale nie są to $\mathrm{w}$ istocie pytania sensu stricto domagające się reakcji odbiorcy, jego odpowiedzi. Świadczy o tym chociażby fakt, że nie można słowem nonsens, absurd lub bzdura odpowiedzieć czy zareagować na pytania o uzupełnienie. Por. nieakceptowalne konteksty:

(16) Kiedy Kasia była na koncercie? - *Nonsens / *Bzdury / *Absurd.

(17) Gdzie byta Kasia? - *Nonsens / *Bzdury / *Absurd.

Również pytania o rozstrzygnięcie w układzie z badanymi wyrażeniami dają podobny efekt. Przykłady (13)-(15) można zaakceptować, jeśli zawarte w nich zdania pytające potraktujemy jako pytania retoryczne, stawiane nierzadko samemu sobie w sytuacjach namysłu nad czymś, zdziwienia czymś czy niedowierzania w coś, wypowiadane często po to tylko, by dać wyraz emocjom. Byłoby to coś w rodzaju częściowo zwerbalizowanej mowy wewnętrznej, obracania w myślach jakichś sądów: własnych lub czyichś, powtórzonych za kimś.

Natomiast rozkazy w funkcji wypowiedzenia poprzedzającego komentujące użycia słów nonsens lub bzdura kłócą się z sensem niesionym przez te wyrażenia. Używa się ich bowiem - co starałam się udowodnić w swoich wcześniejszych pracach (por. Wołk 2007b i 2007c) - do odrzucenia komentowanego przez

${ }^{6}$ Por. przykładową dialogową wersję, w której to zdanie mogłoby się pojawić: Piotr wyjechat do Warszawy, kupit sobie tam mieszkanie i teraz się urządza. - To nonsens, że Piotr kupit sobie mieszkanie $w$ Warszawie. - To nonsens, że on kupit sobie mieszkanie w Warszawie? To pojedź do niego i sprawdź sama. 
nie sądu, któremu przypisuje się za ich pomocą nieprawdę. Nonsens lub bzdura są więc przykładalne jedynie do sądów mających wartość logiczną, a rozkaz jest tej własności pozbawiony. Stąd dewiacyjność układów w rodzaju:

(18) Sprawdź, co w tym tygodniu graja w kinie! - *Nonsens!

(19) Zrób kawę! - *Bzdura!

Nie najlepsza (choć już nie rażąca) będzie również konfiguracja wolnego od związków z wartościowaniem logicznym (dowód na to przedstawiłam w: Wołk 2009a) wypowiedzenia Absurd z rozkazem, por.:

(20) Przeproś go! - ?Absurd!

Tyle że jego akceptowalność może zależeć od sytuacji, w której zostaną wypowiedziane te kwestie, dla jej uczestników może ona być na tyle „przejrzysta”, że taki układ uznają za dobry i całkowicie naturalny. W zasadzie już uzupełnienie kontekstu prawostronnego o sąd uzasadniający czy też rozwijający taką reakcję rozwiewa początkowe wattpliwości, por::

(20') Przeproś go! - Ja mam go przepraszać po tym, jak mnie potraktowat w obecności wszystkich? Absurd!

Podobnie można by próbować ratować akceptowalność przykładów (18) i (19). I o ile układy z nonsensem, po dodaniu do tego wyrażenia sądu wykluczającego możliwość zajścia stanu rzeczy komunikowanego w rozkaźniku, można uznać za dopuszczalne, o tyle bzdura jest na takie zabiegi oporna - część deskryptywna poprzedzająca to wyrażenie musi poddawać się wartościowaniu logicznemu w sposób autonomiczny (tj. bez dodatkowych uzupełnień). Por. akceptowalny przykład (18') z dewiacyjnym (19'):

(18') Sprawdź, co w tym tygodniu graja w kinie! - Nonsens! Tkwimy tu od kilku dni, jesteśmy odcięci od świata, nie mamy telefonów ani komputera.

(19’) Zrób kawę! - *Bzdura! Przecież od rana leci z kranu brudna woda.

Jak widać, mniejsza restrykcyjność układów komentujących jest w dużej mierze pozorna, bo pod kostiumem gramatycznym pytania kryje się $\mathrm{w}$ istocie jakieś stwierdzenie (por. (13)-(15)), a odrzucenie rozkazu za pomocą wyrażenia nonsens lub absurd wymaga dopowiedzenia wyjaśniającego taką reakcję, tłumaczącego istotę orzekanego absurdu czy nonsensu (por. (17’) i (20’)). 
W tym właśnie przejawia się liberalność tych kontekstów: w możliwości zarówno prawo-, jak i lewostronnego ich rozbudowywania. To ich szczególna właściwość. Pozioma kreska w zapisie oznaczająca otwieraną przez dany predykat pozycję syntaktyczną zwykle stanowi miejsce dla frazy zdaniowej. Tak jest w wypadku kontekstów typu to nonsens, $\dot{z} e$ _. Ale w wypadku układów (To) Nonsens. jest to w zasadzie miejsce nie dla zdania, lecz dla w y p ow ied zi jednostki z planu parole, a nie langue, faktycznej jednostki porozumiewania się, która może mieć postać tekstu jedno- lub wielowypowiedzeniowego. Stąd zróżnicowanie graficzne tych kresek w zapisie analizowanych układów: krótka kreska oznacza dopełnienie zdania, wzdłużona sygnalizuje możliwą sekwencję zdań. Jak pokazują przywołane wyżej przykłady (por. (7’)-(12’), (18’) i (20’)), opisywane wyrażenia bywają wplecione w tekst, często dłuższy tekst, którym może być nawet cała opowieść skwitowana np. słowem nonsens przez jej autora lub odbiorcę. Zamiana kontekstów komentujących w propozycjonalne jest więc w zasadzie, z metajęzykowego punktu widzenia, przekształceniem wypowiedzi w zdanie, w którym musi zostać jeśli nie wytłumaczona, to chociażby zarysowana istota nonsensu, bzdury czy absurdu komentowanego zjawiska. Samo wprowadzające zdanie że jest sygnałem tego, że czyjaś wypowiedź jest przytaczana, nie cytowana ${ }^{8}$, a więc przekazywana „w przybliżeniu”, nie ze względu na formę, lecz na treść (por. Wajszczuk 2005: 163).

Nietrudno jednak się domyślić, że relacje między układami komentującymi . (To) Nonsens. a propozycjonalnymi to nonsens, że_ będą wyglądać zgoła inaczej niż między opisanymi przez A. Dobaczewskiego dopowiedzeniami a występującymi wtórnie w funkcji dopowiedzenia leksemami m.in. oczywiście, naturalnie czy jasne. W tych ostatnich bowiem wypowiedź-reakcja (posługuję się terminami, które autor przejął od Chojak) stanowi niemal symetryczne (z konieczną zmianą tego, co zmienić trzeba, a więc kategorii gramatycznych) odbicie wypowiedzi-akcji, por. np.: Rozmawiałeś z dyrektorem? - Oczywiście, że rozmawiatem z dyrektorem (Dobaczewski 1995: 242). Podczas gdy w interesujących mnie kontekstach pojawia się często trudność zmieszczenia w jednej krótkiej frazie zdaniowej sensu całej, nierzadko obszernej, wypowiedzi. Dość dobrze ilustruje to zestawienie zdania (4) z następującym przykładem:

7 Na temat opozycji zdanie - wypowiedź zob. np. w: Bachtin 1986: 356-366, por. też Chojak 2006: 89.

${ }^{8}$ O różnicach między cytatem a przytoczeniem zob. Wajszczuk 2005: 154-184. 
(21) Prawie całe zebranie trwat spór o tę wczorajsza, nieszczęsna ucieczkę z ostatniej lekcji. Część uczniów, chyba nawet większość, rzeczywiście nie przyszła na historię. Oczywiście zaznaczono im w dzienniku nieobecność na tej lekcji. Ale nieobecność ma też Marysia. Klasa miała wczoraj tylko trzy lekcje. Na pierwszych dwóch godzinach polonistka nie sprawdziła obecności, więc z zapisu w dzienniku wynika, że Marysia była w szkole, a potem uciekła wraz z innymi uczniami z ostatniej lekcji. Tak twierdzi nauczycielka. - Marysia uciekła wczoraj $z$ ostatniej lekcji. To nonsens! Przecież jej tego dnia w ogóle nie było w szkole.

Zasadniczo jednak porównywane układy nie różnią się od siebie pod względem znaczenia. Jeśli zestawimy przykład (1) z (7), a właściwie z (7'), to widać wyraźnie, że treści tych zdań pozostają takie same. Potwierdzają to sprzeczne zdania:

(22) *Mówiqu: „, to absurd” o tym, że sekretarka krzyczy na swego szefa, nie mówię, że to absurd, że sekretarka krzyczy na swego szefa.

(23) *Mówiqc: „,nonsens” o tym, że Piotr kupit sobie mieszkanie w Warszawie, nie mówię, że to nonsens, że Piotr kupit sobie mieszkanie $w$ Warszawie.

Zmienia się natomiast uporządkowanie tychże treści w obrębie wypowiedzenia, kolejność, w jakiej występują części tematyczna i rematyczna. Sygnalizuje to już miejsce poziomej kreski w ich schematycznym zapisie. W zdaniach z wyrażeniem to nonsens, $\dot{z} e \_$temat następuje po remacie, a więc najpierw orzeka się na przykład nonsens, a dopiero później jest powiedziane o treści komentowanego sądu, najpierw mówię coś (remat), a później mówię, o czym ${ }_{\mathrm{y}} \operatorname{coś}_{\mathrm{x}}$ powiedziałam (temat). Natomiast w układach komentujących najpierw pojawia się tematyczna „zapowiedź”, czyli to, o czym coś $_{\mathrm{x}}$ zostanie powiedziane, a następnie mówi się cośs o czymśs, wypełnia się tę tematyczną „zapowiedź” treścią (rematem). W pierwszej kolejności tłumaczy się w nich, na czym nonsens (bzdura czy absurd) polega, zarysowuje się sytuację, co - ze względu na „wypowiedziowy" charakter tej części - nie jest trudne, po czym się tę wypowiedź komentuje. Natomiast w kontekstach typu to nonsens, że_orzeka się coś (ściślej: nonsens) o czymś, co dopiero później zostanie wyróżnione i stanie się obiektem czyjejś wiedzy. Dochodzi więc w istocie do niezgodności między linearyzacją a strukturalizacją treści. Nienaturalność kontekstów typu to nonsens, że_bierze się za- 
tem z nienaturalnej hierarchizacji treści komunikowanych w zdaniach realizujących takie układy ${ }^{9}$.

4. W ramach tych rozważań na najtrudniejszym etapie analizy semantycznej, jakim jest sporządzanie eksplikacji, poprzestanę na układach z wyrażeniem nonsens, choć wnioski wysnute z przeprowadzonych wyżej rozważań można pewnie z grubsza odnieść także do dwóch pozostałych wyrażeń, które pojawiły się w przywoływanych przykładach. Znaczenie analizowanych układów z wyrażeniem nonsens proponuję wstępnie objaśniać za pomocą następujących formuł:

(24) p. (To) Nonsens.

'o czymś, o czym ktoś ${ }_{\mathrm{i}}$ powiedział: $\mathrm{p}$, ktoś ${ }_{\mathrm{j}}$

$\mathrm{z}$ tego powodu, że nie jest tak, że i $\mathrm{p}_{1} \ldots \mathrm{p}_{\mathrm{n}}$, i p,

powiedział, że $\sim$ p'

(gdzie $p$ oznacza w y pow ie dź na temat komentowanego zdarzenia lub stanu rzeczy, $p_{1} \ldots p_{n}$ - przesłanki, którymi dysponuje mówiący; ktoś może być tożsamy z kimśs w wypadku, kiedy części składające się na całość analizowanego układu nie tworzą sekwencji dialogowej).

(25) to nonsens, że p

'o czymś, o czym ktoś powiedział, że p, ktoś powiedział, że $\sim p$,

bo nie jest tak, że i $\mathrm{p}_{1} \ldots \mathrm{p}_{\mathrm{n}}$, i p $\mathrm{p}^{\prime 10}$

(gdzie $p$ oznacza zdanie, w którym jest coś powiedziane na temat komentowanego zdarzenia lub stanu rzeczy).

Por. także przykładowe interpretacje wypowiedzeń konstytuowanych przez zdefiniowane wyżej jednostki:

(26) Marysia uciekła wczoraj z ostatniej lekcji. - To nonsens. 'O pewnym zdarzeniu, o którym ktoś powiedział: Marysia uciekła wczoraj z ostatniej lekcji, ktoś $_{\mathrm{j}}$ z tego powodu, że nie jest tak, że Marysi nie było wczoraj w szkole i jed-

9 W tym kierunku radził mi zmierzać Prof. Maciej Grochowski, który w jednej z inspirujących rozmów ujął rozważany problem explicite.

10 Formuła ta stanowi nieznacznie przebudowaną wersję eksplikacji zaproponowanej w: Wołk 2007c: 416. 
nocześnie Marysia uciekła wczoraj z ostatniej lekcji, powiedział, że nieprawdą jest, że Marysia uciekła wczoraj z ostatniej lekcji'

(27) To nonsens, że Marysia uciekła wczoraj z ostatniej lekcji. 'O pewnym zdarzeniu, o którym ktoś powiedział, że Marysia uciekła wczoraj z ostatniej lekcji, ktoś powiedział, że nieprawda jest, że Marysia uciekła wczoraj z ostatniej lekcji, bo nie jest tak, że Marysi nie było wczoraj w szkole i jednocześnie Marysia uciekła wczoraj z ostatniej lekcji’

Definicje te zostały pomyślane tak, by zdawać sprawę z istotnych dla przeprowadzonych rozważań ustaleń, przede wszystkim z cech różniących porównywane układy. Po pierwsze, z różnicy w strukturze tematyczno-rematycznej - formuły te odwzorowują kolejność, w jakiej następują po sobie części tematyczna i rematyczna, tak jak to wygląda w zdaniach realizujących te schematy syntaktyczne. Po drugie, ze sposobu wprowadzania propozycji (odpowiadajacej tu części tematycznej): $\dot{z} e$ pojawiające się w formule (25), w (24) zastępuje dwukropek, który w tym wypadku nie jest sygnałem zwolnienia mówiącego od odpowiedzialności, za to, co mówi, bo nie mamy tu do czynienia z relacjonowaniem mówienia ${ }^{11}$, lecz zapowiada czyjąś wypowiedź w jej pełnym, niezmienionym i „niesyntetycznym” kształcie. I ostatnia - jednak dość ważna - wiążąca się z ostatnim stwierdzeniem rzecz: nawiasowa uwaga do definicji uściślająca zakres odniesienia $p$ precyzuje jednocześnie cechy językowe sądu będącego przedmiotem komentarza.

Przedstawione eksplikacje nie pretendują do roli ostatecznych charakterystyk semantycznych opisywanych wyrażeń. Traktuję je jako pewien etap w myśleniu nad znaczeniem analizowanych słów. W dalszych badaniach trzeba byłoby nadać tym formułom taką postać, by uniknąć ryzyka opisania za ich pomocą innych predykatów służących do zanegowania czyichś sądów, takich jak np. ktoś zakwestionowat coś czy ktoś zaprzeczyt czemuś.

5. W zakończeniu (które można potraktować jako swoisty epilog) tej analizy chciałabym jeszcze skierować swoją uwagę na sprawę dla tych rozważań nie najważniejsza, ale z punktu widzenia całości prowadzonych przeze mnie badań istotną. Wiąże się ona z problemem przekształcenia układów komentują-

11 Na różnicę między wprowadzającym zdanie że a dwukropkiem zwróciła uwagę Wajszczuk (2005: 162-164), jednak najdobitniej wyraził ją i zobaczył w nowym świetle A. Bogusławski w opisie „powiedzenia, że” i „powiedzenia:_” (cytacyjnego), por. np. Bogusławski 2005, Bogusławski 2007: 423-506. 
cych w propozycjonalne, a dotyczy statusu opisywanych wyrażeń. Chodzi mianowicie o rozstrzygnięcie, czy opisywane ciągi, takie jak np. to nonsens, $\dot{z} e_{-}$, to absurd, $\dot{z} e_{\text {, }}$ to bzdura, $\dot{z} e_{-}$, są konstrukcjami czy jednostkami języka (w rozumieniu Bogusławskiego 1976). Rzecz sprowadza się zatem do ustalenia, czy połączenia takie wpisują się w serię i są wynikiem regularnych operacji wykonywanych na języku, czy też stanowią gotowe całości, niepodzielne formalnie i funkcjonalnie. W ustalaniu ich statusu trzeba by przede wszystkim sprawdzić, czy w miejsce poszczególnych segmentów składających się na interesujące nas ciągi można wstawić jakieś inne wyrażenia. W zasadzie w grę wchodzi tu tylko drugi (rzeczownikowy) i trzeci (włącznikowy) segment, ponieważ otwierający te ciagi zaimek to pełni jedynie funkcję swoistej podpórki syntaktycznej. Jeżeli chodzi o wprowadzające propozycję $\dot{z} e$, to podlega ono substytucji wyłącznie przez żeby (i ewentualnie jakoby), tworząc połączenia to nonsens, $\dot{z} e b y_{-}$, to absurd, żeby_i to bzdura, żeby_ ${ }^{12}$, niedopuszczalne są bowiem ciągi z innymi operatorami, por. np. dewiacyjne *to nonsens, jak / kiedy / gdzie_. Jak już wcześniej wspomniałam, w miejscu drugiego segmentu mogą się pojawić zarówno inne rzeczowniki (np. prawda, zgoda, szkoda), jak i przymiotniki, przysłówki lub partykuły. Jeśliby jednak zbiór tych wyrażeń zawęzić do takich, które zbliżają się semantycznie do interesującego mnie nonsensu, to otrzymamy zestaw, w którym obok akceptowalnych połączeń z opisywaną tu trójką na czele i ciągami to głupstwo, że_i to brednie, że_, znajdą się również ciągi niedopuszczalne, np. *to glupota, $\dot{z} e_{-}$, *to pierdoty / bzdety / dyrdymaty / herezje, $\dot{z} e$, i także dewiacyjne według mnie wyrażenia *to niedorzeczność, $\dot{z} e_{-}$i *to bezsens, $\dot{z} e$. Sądzę, że nieakceptowalność dwóch ostatnich wynika z tego, że słowa niedorzeczność i bezsens nie pełnią w wypowiedzeniach funkcji predykatów podstawowych konstytuujących zdanie, lecz występują w pozycji argumentu nieprzedmiotowego implikowanego przez tenże predykat, por. np. Westchnat $w$ duchu nad swoja głupota i bezsensem sytuacji., Szef od razu zwrócit uwage na niedorzeczność tego planu. Natomiast nieakceptowalność poprzedzających je wyrażeń należałoby tłumaczyć własnościami pragmatycznymi rzeczowników wchodzących w skład badanych ciagów. Bo zauważmy, że z dewiacyjnym wyrażeniem *to głupota, że_z nacechowanym słowem głupota kontrastuje dobre połączenie to głupstwo, że_z neutralnym stylistycznie słowem głupstwo. Tę obserwację można by rozciągnąć także na inne wyrażenia, odległe semantycznie od opisywanych w tym tekście. Występujące często w układach komentujących

12 Opis zdań z tymi wyrażeniami przedstawiłam w: Wołk 2009 b. 
potoczne ekspresywizmy, takie jak np. katastrofa, horror, masakra (por. np. Ale tu goraco! Masakra) czy popularne ostatnio w slangu młodzieżowym określenie hardcore, wstawione w układy propozycjonalne dają dewiacyjne ciagi, por. *To masakra, że jest tak goraco (por. także niedobre *to horror / katastrofa / hardcore, że_). Wydaje się, że im niższe „wymagania towarzyskie” danej sytuacji, im bardziej potoczne czy pospolite jest dane wyrażenie, tym mniejsza jest jego zdolność do wystąpienia w układzie propozycjonalnym z że. Ze względu na brak precyzyjnego aparatu metodologicznego, za pomocą którego można by opisywać własności pragmatyczne wyrażeń, ocena ich nacechowania potocznością, a w szczególności rozpoznanie „stopnia” potoczności czy umieszczenie ich na „skali” potoczności, zawsze będzie eksperymentem, w którym intuicja i arbitralne rozstrzygnięcia wezmą górę nad ustaleniami poczynionymi w drodze sprawdzania wysuwanych hipotez i twierdzeń. W żaden sposób nie da się bowiem udowodnić, że słowo bzdura występujące w układzie to bzdura, że, choć w porównaniu z nonsensem jest nacechowane potocznością, to jednak w zestawieniu z wyrażeniami takimi, jak np. głupoty, pierdoły czy bzdety, wydaje się bardziej neutralne czy też mniej pospolite niż one.

Wracając do podjętego w tym fragmencie wątku dotyczącego statusu połączeń w rodzaju to nonsens, że_, należałoby je według mnie uznać nie za konstrukcje, lecz za jednostki języka ${ }^{13}$. Przemawia za tym fakt bardzo ograniczonej substytucji że za pomocą innych operatorów, a także to, że nie wszystkie bliskoznaczniki wyrażenia nonsens dają się wstawić w rozważane układy propozycjonalne. To ostatnie spostrzeżenie podsuwa jednocześnie wątpliwości dotyczące bliskości semantycznej wyrażeń występujących jako drugi segment analizowanych ciagów. Niewykluczone, że niemożność wystąpienia danego słowa w rozważanym układzie jest sygnałem pewnych różnic semantycznych oddalających od siebie te wyrażenia na tyle, że mówienie o ich bliskości znaczeniowej mogłoby być wnioskiem zbyt pochopnym.

13 Jeśli chodzi o wyrażenia takie, jak np. oczywiście, że_, pewnie, że_, czy właśnie, że_, to zostały one przez Dobaczewskiego najpierw uznane za jednostki języka (por. Dobaczewski 1998: 34), a później (por. Dobaczewski 1999: 25) za konstrukcje (ze względu na możliwość podania charakterystyki ogólnej poprzedzających że „dopowiedzeń”). 


\section{Bibliografia}

Bachtin M., 1986, Estetyka twórczości słownej, Warszawa: Państwowy Instytut Wydawniczy.

BogusŁawski A., 1976, O zasadach rejestracji jednostek języka, Poradnik Językowy 8, s. 356-364.

BogusŁawski A., 2005, Do teorii czasownika powiedzieć, Polonica XXIV-XXV, s. 139-155 .

BogusŁawski A., 2007, A Study in the Linguistics-Philosophy Interface, Warszawa: BEL Studio.

CHолак J., 2006, Semantyka i składnia czasowników oznaczajacych reakcje stowne, Warszawa: Wydawnictwa Uniwersytetu Warszawskiego.

Dobaczewski A., 1995, O leksemach oczywiście i naturalnie, Zeszyty Naukowe WSP w Olsztynie. Prace Filologiczne 1, s. 241-253.

Dobaczewski A., 1998, Cechy sktadniowe i semantyczne polskich dopowiedzeń potwierdzajacych, Warszawa: Katedra Lingwistyki Formalnej UW.

Dobaczewski A., 1999, Próba opisu znaczeń leksemów jasny / jasno / jasne, Prace Językoznawcze UWM 1, s. 17-26.

Grochowski M., 1997, Wyrażenia funkcyjne. Studium leksykograficzne, Kraków: Wydawnictwo Instytutu Języka Polskiego PAN.

ISJP: Inny słownik języka polskiego, red. M. Bańko, 2000, t. 1-2, Warszawa: Wydawnictwo Naukowe PWN.

LASKowski R., 1999, Zagadnienia ogólne morfologii, w: R. Grzegorczykowa, R. Laskowski, H. Wróbel (red.), Gramatyka współczesnego języka polskiego. Morfologia, Warszawa: Wydawnictwo Naukowe PWN, s. 27-86.

PSWP: Praktyczny słownik wspótczesnej polszczyzny, red. H. Zgółkowa, 1994-2005, t. I-L, Poznań: Kurpisz.

SJPSz: Słownik języka polskiego, red. M. Szymczak, 1988-1989, t. 1-3, Warszawa: PWN.

SWJP: Stownik wspótczesnego języka polskiego, red. B. Dunaj, 1996, Warszawa: Wilga.

USJP: Uniwersalny słownik języka polskiego, red. S. Dubisz, 2003, t. 1-6, Warszawa: PWN.

Wasszczuk J., 2005, O metatekście, Warszawa: Katedra Lingwistyki Formalnej UW.

Wierzbicka A., 1973, Akty mowy, w: M. R. Mayenowa (red.), Semiotyka i struktura tekstu, Wrocław: Zakład Narodowy im. Ossolińskich, s. 201-219.

WiśNIEWSKi M., 1995, O funkcjach gramatycznych wyrażeń typu oczywiście, pewnie, wykluczone, w: M. Grochowski (red.), Wyrażenia funkcyjne w systemie i tekście, Toruń: Wydawnictwo UMK, s. 159-170. 
WoŁk M., 2007a, Cechy syntaktyczne wyrażeń nonsens i absurd. Wprowadzenie do opisu semantycznego, w: B. Brehmer, V. Ždanova, R. Zimny (red.), Beiträge der Europäischen Slavistischen Linguistik (POLYSLAV), t. 10, München: Otto Sagner, s. $178-187$.

WoŁK M., 2007b, Czym bzdura nie jest, a czym jest? Analiza semantyczna wyrażenia bzdura, w: J. Kamper-Warejko, I. Kaproń-Charzyńska (red.), Z zagadnień leksykologii i leksykografii języków stowiańskich, Toruń: Wydawnictwo Naukowe UMK, s. 295-302.

WoŁк M., 2007c, W stronę semantyki nonsensu, Prace Filologiczne LII, s. 409-418.

WoŁк M., 2009a, O absurdzie. Rozważania semantyczne, Linguistica Copernicana 1, s. $111-126$.

WoŁk M., 2009b, Zdania typu $p$, żeby / że $q$ a problem definiowania wyrażenia nonsens i jego bliskoznaczników, Polonica XXIX, s. 117-130.

\section{About the types of expressions ___. (To) Nonsens. (vs to nonsens, że_) from a semantic point of view}

\section{( s u m mary)}

The range of this article is slightly wider then its title suggests. I develop here the idea which I have initiated in a few of my earlier papers about the expression nonsens and some of its synonyms. I am mainly interested in a certain type of configuration, where the words nonsens, absurd and bzdura appear, for example in the sentence Marysia uciekla wczoraj $z$ ostatniej lekcji. To nonsens! / Nonsens 'Mary skipped her last class yesterday. This is nonsense! / Nonsense.' I investigate the grammatical status of the expression nonsens in such contexts, which I have called commenting ones, but primarily I am focused on what determines the difference between the example given above and a sentence such as $T o$ nonsens, że Marysia uciekta wczoraj z ostatniej lekcji 'This is nonsense that Mary skipped her last class yesterday'. I examine whether the difference has a semantic character and if so, how it should be defined. Since the procedure of comparing the expressions which follow the model given in the title opens more problems, which I have described in earlier papers, in this article I investigate the issues which I have so far only implied or examined marginally with relation to other crucial aspects of nonsense, such as the issue of metalinguistic character of the described expressions. 